\title{
Muskau Arch Geopark in Poland (Central Europe) — Is it Possible to Integrate Geoconservation and Geoeducation into Biodiversity Conservation?
}

\author{
Krzysztof Świerkosz $^{1}$ (D) Jacek Koźma $^{2} \cdot$ Kamila Reczyńska $^{1} \cdot$ Marek Halama $^{1}$
}

Received: 5 July 2015 / Accepted: 15 March 2016 / Published online: 30 March 2016

(C) The Author(s) 2016. This article is published with open access at Springerlink.com

\begin{abstract}
The Muskau Arch Geopark, situated on the PolishGerman border, belongs to the UNESCO Global Geopark Network and is a model example that allows for the examination of the relationship between geo- and biodiversity as present in preservation, tourism, and management. In this area, there are 31 geotopes representing both natural geological processes as well as remnants of the cultural heritage associated with the region's industrial history. The geodiversity of the area is well-documented, while data on its biodiversity are rudimentary. Attaining a supplement was the one of the aims of this study. In the Polish part of the geopark, besides objects of geological heritage, nine types of natural habitats were found, which contained 634 species of vascular plants; 220 fungi species; 76 lichens; 42 species of amphibians, reptiles and mammals; and 146 species of birds. Spatial analysis revealed that $54.2 \%$ and $53.8 \%$ of the recognized valuable plant and animal sites, respectively, are located less than $1 \mathrm{~km}$ from the nearest geotope and nearly $100 \%$ of these sites are located within $5 \mathrm{~km}$ of one. In the area of the Muskau Arch Geopark,
\end{abstract}

Krzysztof Świerkosz

krzysztof.swierkosz@life.pl

Jacek Koźma

Jacek.Kozma@pgi.gov.pl

Kamila Reczyńska

kamila.reczynska@gmail.com

Marek Halama

marek.halama@uwr.edu.pl

1 Museum of Natural History, Wrocław University, Sienkiewicza 21, 50-355 Wroclaw, Poland

2 Polish Geological Institute, National Research Institute, Lower Silesian Branch, Jaworowa 19, 53-122 Wroclaw, Poland geodiversity and biodiversity values are of equal importance, yet they are separated at the landscape scale. The majority of valuable geoheritage geotopes are the result of previous anthropogenic activities. However, contemporary areas of high natural value are parts of previously existing ecosystems of a natural or semi-natural character, coming from the period before the mining of mineral deposits by humans. A more integrated approach to conservation would benefit both the biodiversity and geodiversity of the Muskau Arch Geopark, would be of interest to tourists, and would increase the scientific and educational attractiveness of the region.

Keywords UNESCO Global Geopark · Geotopes · Natural habitats $\cdot$ Endangered species $\cdot$ Educational attractiveness . Geotourism · Natura 2000

\section{Introduction}

Geodiversity and biodiversity are intimately linked, from the microscopic scale to the broadest landscape, and the issue of their successful integration in conservation has been repeatedly addressed (e.g., Bruneau et al. 2011; Crofts 2014; Crofts and Gordon 2015). Many authors emphasize that geodiversity is the foundation of all terrestrial ecosystems, delivering many essential support services for biodiversity (Gordon and Barron 2012; Gordon et al. 2012; Gray 2005; Gray et al. 2013). Recent, more detailed analyses of direct measures of geodiversity appear to be promising proxy of biodiversity, which both directly and indirectly reflect important abiotic resource factors (e.g., Alexandrowicz and Margielewski 2010; Hjort et al. 2012).

The interplay of geo- and biodiversity in geoconservation occurs mainly at the landscape scale (Bruneau et al. 2011), as geodiversity determines landscape diversity (Gordon and 
Barron 2012). Hence, the protection of geotopes at the landscape level can be carried out in the most effective manner using various kinds of sites, from "Natural monuments or features" up to "Protected areas with sustainable use of natural resources" (Crofts and Gordon 2015; Gordon et al. 2015).

For this reason, many of the current studies on geoheritage concern not only purely abiotic objects but also emphasize the coexistence and interdependence between them and biotic elements (e.g., Gray 2005). In practice, these relations can take on different characters depending on the history and degree of development of a particular region (Matthews 2014). Within areas with well-preserved flora and vegetation and low anthropogenic pressure, geotopes of natural character are mainly represented. In these places, it appears that biodiversity and geodiversity are in a harmonious relationship, both with regards to their origin and their location (e.g., Santucci 2005; Musila et al. 2005; Houshold and Sharples 2008; Moreira 2010; Alexandrowicz and Margielewski 2010; Erikstad 2014).

On the other hand, there are areas which have been actively transformed during the processes of urbanization and mineral extraction, where the increase in the number of geotopes may be accompanied by a sustained decline in biodiversity, both at the ecosystem level as well as for individual populations of plants and animals (Petrişor and S bru 2010). Following this, one of two things can happen. The ecosystems which were destroyed by exploitation may be replaced by other valuable habitats during the process of succession (Wheater and Cullen 1997; Badora et al. 2003; Beneš et al. 2003; Novák and Prach 2003; Jędrzejczyk-Korycińska 2006; Babczyńska-Sendek et al. 2012; Bétard 2013). Alternatively, the succession may result in the development of communities which are synanthropic in character and are deprived of high biotic value (Szczęśniak 1999; Nowak and Nowak 2013). In extreme cases, intense spatial management threatens both geo- and biocomplexes and can lead to the irreversible destruction of these components in the environment (Kiernan 2010).

That might be one reason for a differential interpretation of the term "geoconservation," which may broadly embrace not only the protection of sites combining natural habitats, geology, geomorphology, or hydrology — all of which directly link biodiversity and geodiversity, but also sites of purely geoheritage significance with high scientific and educational value (Brocx and Semeniuk 2007).

A model example for examining the relationship between geo- and biodiversity present under sustainable land use and tourism is the Polish part of the Muskau Arch Geopark (Fig. 1). Its borders include a transboundary glaciotectonic structure which spans the Polish-German border (Kupetz and Kupetz 2009; Koźma and Kupetz 2008; Koźma 2011). One of the elements of the geopark is Muskauer Park/Park Mużakowski, which is included, along with 14 other areas in Poland (Alexandrowicz et al. 2009) and 40 areas in Germany (http://whc.unesco.org/en/statesparties/de; access 4.02.2016), in the list of UNESCO World Heritage Sites.

The main purpose of the present study is to determine the spatial relations between abiotic and biotic elements in order to verify whether they can be incorporated into educational and tourist activities in the area or if they are spatially isolated. A simultaneous goal is to describe the status of natural habitats, vascular flora, and mycobiota within the study area. We further aim to find out whether the abundance of geotopes in the anthropogenic environment is accompanied by an increase or decrease in biodiversity.

\section{Study Area}

\section{Location}

The study area covers the area of the Muskau Arch Landscape Park in Poland, with acreage of 18,200 ha, established in 2001 to protect the post-glacial landscape consisting of relics of the open-cast mining industry as well as the remaining fragments of natural ecosystems. The Muskau Arch Landscape Park is located in the eastern part of the transborder Polish-German Muskau Arch Geopark (Fig. 1).

In 2013, the geopark was included in the European Geopark Network, as the 42nd of 65 geoparks currently known in Europe which have the support of UNESCO. The boundaries of the geopark and the landscape park include a glaciotectonic moraine structure. This structure extends from the vicinity of the village Döbern (Brandenburg) in the direction of Weißwasser (Saxony) on the German side and then from Łeeknica towards Trzebiel, to the village of Tuplice, on the Polish side (Lubuskie Province). The push moraine covers roughly the area of a triangle with sides of $25 \mathrm{~km}$ but it has the characteristic shape of a horseshoe, open to the north, which reflects the outline of a small glacial lobe.

The differences in the altitude range from $90 \mathrm{~m}$ a.s.l. (Nysa Łużycka Valley) to $182.8 \mathrm{~m}$ a.s.l. (morainic upland), which gives the area a varied landscape. The climate is one of the warmest in Poland. The mean annual temperature reaches $8.0^{\circ} \mathrm{C}$, whereas the rainfall varies between 500 and $600 \mathrm{~mm}$ per year.

\section{Geodiversity}

The Muskau Arch Geopark, whose eastern part is included in the study area, is a glaciotectonic structure formed during the Marine Oxygen Isotope Stage (MIS) 12 (Kupetz 1997). Its internal geology structure was investigated and assessed in detail owing to the drilling and mining works which took place within it. Based on these assessments, it is assumed that during the transgression of the lobe, which originated during 


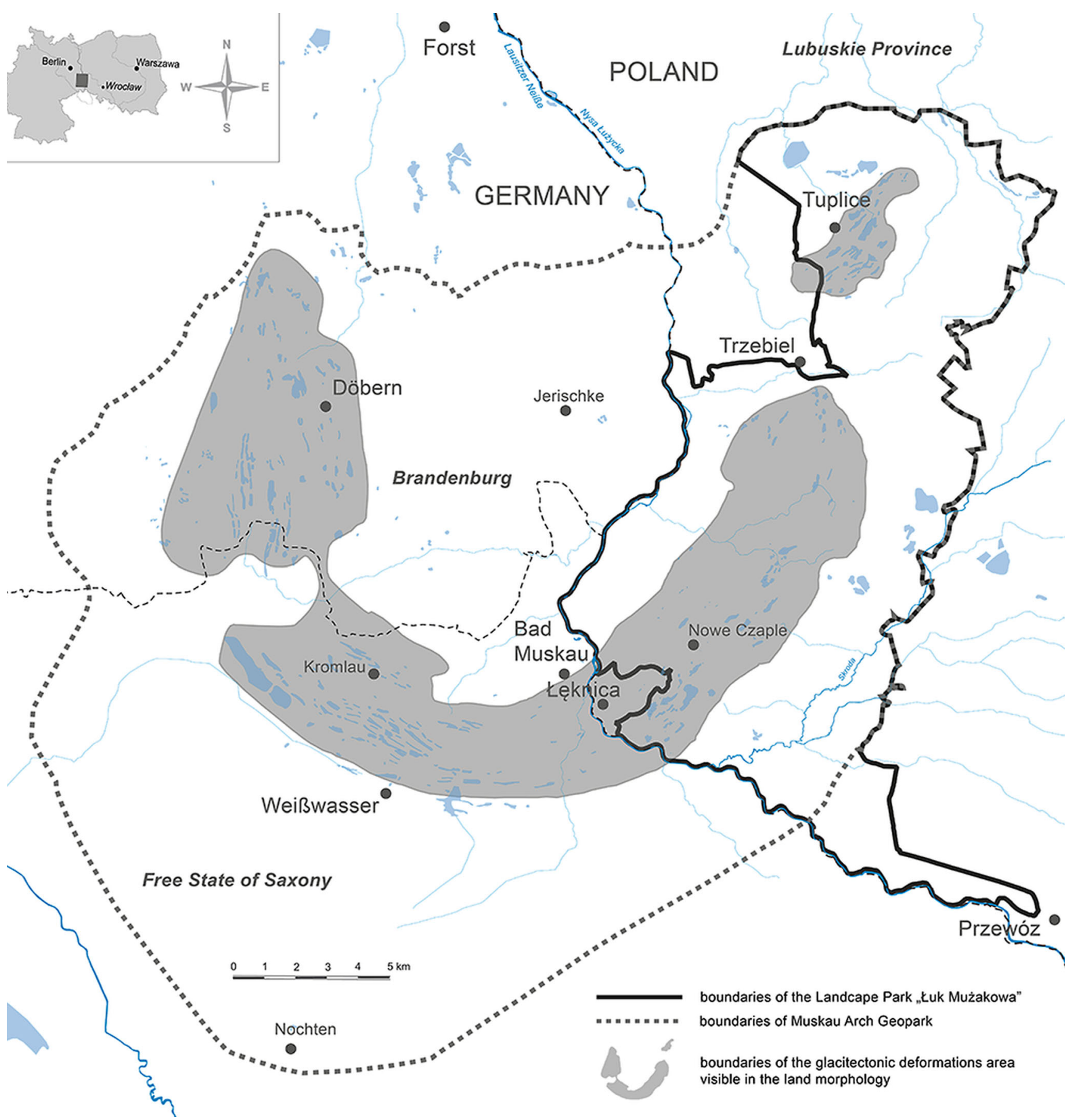

Fig. 1 Location of the Muskau Arch Landscape Park (study area) layered over the European, cross-border Muskau Arch Geopark and glaciotectonic deformation area

the MIS 12 ice limit (ca. $450 \mathrm{ka}$ ), a rampart was formed within its foreland, consisting of disturbed glaciotectonic sediments from both the upper and middle Miocene as well as the older quaternary deposits (Dyjor and Chlebowski 1973). In the later period, during the MIS 6 , the original moraine form became strongly eroded and, as a result, its height was significantly reduced (Kupetz 1997). Currently, sediment formations pressed out by the glacier, originating in the MIS 12 ice limit, are preserved in a rudimentary form, and the hills of the front moraines reach a relative altitude of several tens of meters. A significant amount of information on the development and origin of the morphological forms of the Muskau Arch and their relation to geology is provided by the analysis of the LIDAR terrain model (Kupetz 2003). On this basis, we can distinguish the distinct features of the geological structure of the study area which contribute to its unique geodiversity. 
Most often, within a push moraine, a clearly belt-shaped arrangement of outcrops of beds of brown coal can be observed, accompanied by other Miocene sediments. The lying near the surface layers of brown coal, which were lifted up from the depth of $150 \mathrm{~m}$, are deflected almost vertically and accompanied by deposits of clays, claylike silts, and finegrained sands from the same age. The brown coal outcrops are visible in the field and on relief models as linearly stretched and longitudinally arranged small depressions, sometimes separated by local hills. These depressions were formed as a result of the weathering and compaction of parts of the brown coal beds which, due to fluctuations in groundwater levels within the aeration zone, became a peat earth. The width of these forms reaches up to $30 \mathrm{~m}$ and the length is up to $2 \mathrm{~km}$, with depth ranging from 3 to $5 \mathrm{~m}$ (max. $20 \mathrm{~m})$. They are often filled with the Holocene alluvia and peats. The belt-shaped depressions, called weathering ditches, are separated by moraine forms of accumulation. The latter are hills made of glacial sediments of sands and gravels left behind as part of the glaciotectonic structures of the MIS 12 .

A crucial element which influences the relationship with geodiversity of the Muskau Arch is widespread anthropogenic deposits, which reflect the former mining of brown coal, ceramic clays, and glass sands. These are mostly sediments of silt and sand with a significant admixture of brown coal. They are acidic due to the infiltration of pyrite weathering products into the soil, surface water, and underground water (Greinert et al. 2009).

The most noticeable features within the post-mining landscape are the numerous artificial pits of various origins, which are filled with water that is low in $\mathrm{pH}$ and high in iron content. Within the borders of the study area these pits form an "anthropogenic lake district" consisting of over 100 reservoirs, which is unique on a European scale. The basins can be divided into two groups, based on their origin - the first ones were formed due to the ground subsidence, while the second ones are the operational centers of the old open-cast mine. In the Polish part of the Muskau Arch, they cover 1195 ha, or $10 \%$ of the total area of the studied region.

The geodiversity of the investigated area has been the subject of many studies concerning its value and the possibilities of tourist use (Rascher et al. 2000; Badura et al. 2002; Kasiński et al. 2004; Koźma and Kupetz 2008; Koźma 2011, 2013). Therefore, the recognition of geological values of the study area is very high and detailed. Within the entire area of the Muskau Arch (both on the Polish and German side), there are 31 single geotopes representing 10 different geotope types (Rascher et al. 2000). They are located at 95 individual sites - notably 34 in Poland, and 12 with unusually high scientific and educational value (Kasiński et al. 2004).

Among the distinctive features of the study area within Polish territory are the acidified lakes within the area of old mining of lignite and the springs of ferrous water; the glacial boulder, gap river valley, river terrace, kettle hole, front and push moraine are also considered to be valuable if not distinct (Kasiński et al. 2004).

\section{Current Knowledge on Biodiversity}

The published data on the biological diversity (biodiversity) of the area include only selected groups of fauna (Jerzak 2005) and the major drawback is the lack of references to the distribution and representation of species protected under the law of the European Union. Moreover, data on the distribution of fungi and lichens in the study area are completely missing, while some information about vascular plants (Jankowski and Świerkosz 1995; Pawlaczyk 1999) is no longer relevant.

Within the Polish part of the Muskau Arch Geopark, there are two Natura 2000 sites. The first one PLH080038 "Legi nad Nysą Łużycką" encompasses the southern part of the landscape park with an area of $0.6 \mathrm{~km}^{2}$. The second Natura 2000 site is PLH080060 "Uroczyska Borów Zasieckich" which covers about $0.4 \mathrm{~km}^{2}$ in the northernmost part of the landscape park.

\section{Methods}

Field studies on the distribution of vascular plants, fungi, and lichens were mainly carried out in 2007 within the Muskau Arch Landscape Park; they were supplemented in later years. The research was conducted following the methodologies specific to each scientific discipline. The vascular plants were examined along routes for the recognition of their diversity within all possible types of habitats-from natural to synanthropic; whereas research on macroscopic fungi and lichens was conducted on model plots which were selected from different types of ecosystems-13 plots for macromycetes and 33 for lichens.

The habitats, which were essential to the maintenance of biodiversity, were selected based on both our own research (for flora, mycobiota, natural habitats) and other sources (for fauna) (Jerzak 2005; Weigle 2007). We focused on geotopes listed by Kasiński et al. (2004). The analyses of the mutual position of the objects were performed using the software QGIS 2.4.0 with vector analysis package fTools 0.6.2.

The nomenclature of species follows Faltynowicz (2003) for lichens, Wojewoda (2003) for macrofungi, and Mirek et al. (2002) for vascular plants. The threatened species categories in Poland are used in accordance with Cieślinnski et al. (2006) for lichens, Wojewoda and Lawrynowicz (2006) for macrofungi, and Kaźmierczakowa et al. (2014) for vascular plants. 


\section{Results}

\section{Ecosystem Biodiversity}

In terms of diversity of vegetation, two separate units can be distinguished within the study area. Both of them coincide with landscape units. The first one is the Nysa Lużycka valley, which runs along the southern and western border of the landscape park and coincides with the Polish-German border. In the ravined section between Bad Muskau and Łeknica, the river valley floor is clearly separated from the adjacent moraine uplands, the edges of which reach the height of 30-40 m. The valley of Nysa Łużycka is occupied by communities which depend on periodical floods; however, the majority of this area has been transformed due to long-lasting human activity and is occupied by croplands. The second unit embraces a much greater part of the landscape park and is covered by synanthropic communities. Dominating here are monocultures with Pinus sylvestris and a high share of neophytes, croplands, and ruderal communities that surround places that are intensively used by humans. Only a small area is occupied by deciduous forests (occurring mainly along streams and in the depressions) or hay meadows; peat bogs and swamps also occur sporadically. These vegetation formations cover the gently undulating post-glacial landscape accompanied by moraine hills.

Within the study area, nine types of natural habitats listed in Annex I of Directive 92/43/EEC (Habitat Directive) were recorded (Table 1). Although, these habitats occupy small areas, they remain an essential element of biodiversity at the ecosystem level.

\section{Plant Biodiversity}

Within the study area, 634 species of vascular plants were found. The most important of these is Apium nodiflorum as its presence here represents the only known location in
Poland. This species is specific to both the geopark and landscape park and its sites near Królów village are under constant scientific observation (Żukowski et al. 2014a). Other species important in Poland are Luronium natans (Annex II of Habitat Directive), occurring near Przewóz in the Nysa Łużycka Valley (Szmeja 2014) and the following species included in the Polish Red Book of Plants: Pilularia globulifera - category CR (Żukowski et al. 2014b), Elatine hexandra and Elatine triandra-category EN (Popiela et al. 2014a, 2014b), Eleocharis multicaulis - category EN (Herbichowa et al. 2014), and Rhynchospora fusca - category VU (Herbichowa and Rosadziński 2014). They are largely located in artificial water reservoirs, whose periodic emptying enables the development of vegetation of ephemeral wetlands (Isoëto-NanoJuncetea Br.-Bl. et Tüxen ex Br.-Bl. et al. 1952).

Also observed among other important vascular plants which are endangered or protected in Poland were Alisma lanceolatum, Allium scorodoprasum, Blechnum spicant, Dactylorhiza maculata, Diphasiastrum complanatum, Drosera rotundifolia, Epipactis helleborine, Erica tetralix, Ledum palustre, Lonicera peryclimenum, Lycopodium annotinum, L. clavatum, Matteucia struthiopteris, Polypodium vulgare, Batrachium aquatile, Urticularia vulgaris, Osmunda regalis, Centaurium umbellatum, Menyanthes trifoliata, and Ononis spinosa.

In recent years, species from the Polish Red Book of Plants such as Montia fontana, Ludwigia palustris, Cuscuta epilinum, Sedum villosum, Carex pulicaris, Arnica montana, Cyperus flavescens, and Spergularia segetalis have not been re-confirmed and have probably become extinct. Among other taxa essential to the biodiversity of the studied region (Pawlaczyk 1999) which were not confirmed during resent research are Aquilegia vulgaris, Carex arenaria, Carlina acaulis, Chimaphilla umbellata, Dactylorhiza majalis, Dianthus arenarius, D. superbus, Drosera anglica, D. intermedia, Epipactis palustris, Gentiana pneumonanthe, Gratiola officinalis, Huperzia selago, Ornithogalum

Table 1 Natural habitats listed in Annex I of Directive 92/43/EEC within the Muskau Arch Landscape Park

\begin{tabular}{llll}
\hline Habitat code and name & Plant community & $\begin{array}{c}\text { Area [ha] } \\
\text { Local importance } \\
\text { for biodiversity }\end{array}$ \\
\hline 3150 Natural eutrophic lakes & All. Nymphaeion and All. Potamion & $<5$ & Important \\
$* 6120$ Xeric sand calcareous grasslands & All. Koelerion glaucae & $<1$ & Weak \\
6430 Hydrophilous tall herb fringe communities & All. Filipendulion & $<1$ & Weak \\
6510 Lowland hay meadows & All. Arrhenatherion elatioris & $<100$ & Weak \\
7140 Transition mires and quaking bogs & Cl. Scheuzerio-Caricetea & $<10$ & Important \\
9130 Asperulo-Fagetum beech forests & Ass. Galio odorati-Fagetum & $<50$ & Very important \\
9170 Galio-Carpinetum oak-hornbeam forests & Ass. Galio sylvatici-Carpinetum & $>150$ & Very important \\
$* 91$ E0 Alluvial forest with Alnus glutinosa and Fraxinus excelsior & Ass. Salicetum albo-fragilis, Fraxino-Alnetum & $<50$ & Important \\
91F0 Riparian mixed forests along the great rivers & Ass. Ficario-Ulmetum campestris & $<10$ & Weak \\
\hline
\end{tabular}


umbellatum, Ononis repens, Pedicularis palustris, and Utricularia minor. Some of them still have potential sites here. However, the reoccurrence of certain species typical of peat bogs (Drosera intermedia, D. anglica, Pedicularis palustris, Epipactis palustris, Utricularia minor) and Molinia meadows (Dianthus superbus, Gentiana pneumonanthe, Gratiola officinalis) is unlikely because their habitats have been irreversibly destroyed.

\section{Fungal Biodiversity}

Preliminary studies revealed the occurrence of at least 220 taxa of macroscopic fungi and 76 species of lichens within the study area. Among macromycetes, 184 taxa were identified at the species level, with 36 at the genus level. One fungus under legal protection (Hydnellum concrescens) and 11 other species which are endangered or vulnerable to extinction in Poland were recorded here. These are endangered species (Boletus queletii, Cortinarius umbrinolens, Hydnellum concrescens, and Lactarius lacunarum); vulnerable species (Ascotremella faginea, Sarcodon imbricatus and Tephrocybe palustris); and rare taxa (Galerina sphagnorum, Fistulina hepatica, Lactarius chrysorrheus and Pisolithus arrhizus).

Both epiphytic species growing on bark and epigeic species occurring on ground dominate among lichens (Dimos in Weigle 2007). In these groups, 22 species included in Annex $\mathrm{V}$ of Habitat Directive should be particularly mentioned (Cladonia arbuscula, Cladonia cenotea, Cladonia chlorophaea, Cladonia coccifera, Cladonia coniocraea, Cladonia cornuta, Cladonia crispata, Cladonia digitata, Cladonia fimbriata, Cladonia foliacea, Cladonia furcata, Cladonia glauca, Cladonia gracilis, Cladonia macilenta, Cladonia ochrochlora, Cladonia phyllophora, Cladonia portentosa, Cladonia pyxidata, Cladonia ramulosa, Cladonia rangiferina, Cladonia subulata, and Cladonia uncialis). Moreover, within the study area, there are also seven species included in the red list of species endangered in Poland (Opegrapha vermicillifera-category EN; Pycnothelia papillaria - category EN; Calicium viride - category VU; Cetraria islandica - category VU; Punctelia subrudecta-category VU; Chaenotheca furfuracea-category NT and Graphis scripta-category NT) and 11 other species protected in Poland (Dimos in Weigle 2007).

\section{Faunal Diversity}

Within the study area, 14 species of amphibians, 6 species of reptiles, 146 species of birds, and 22 species of mammals protected in Poland were found. However, the most important are the taxa which are under protection in the European Union and which have a significant representation here.
Of these for amphibians and reptiles included in Annex IV of Habitat Directive there are Rana arvalis, $R$. ridibunda, Pelobates fuscus, Hyla arborea, Bufo viridis, Bombina bombina, Triturus cristatus, Lacerta agilis, and Coronella austriaca.

Among mammals protected in the EU, 11 species of bats and Lutra lutra occur. The study area is located within the territory of Canis lupus which lives in the transboundary Polish-German region and whose range gradually extends towards the lowlands of Southwestern Poland.

With reference to birds, those which are both listed in Annex I of Birds Directive and nesting within the study area are Botaurus stellaris, Bucephala clangula, Haliaeetus albicilla, Milvus milvus, M. migrans, Circus aeruginosus, Grus grus, Alcedo atthis, Lanius collurio, Picus viridis, Dendrocopos medius, and Ciconia nigra (Jerzak 2005; Weigle 2007).

\section{The Most Important Threats to Biodiversity}

Currently, the main threat to the biodiversity of the study area is the presence of 24 species of invasive vascular plants. The most serious problem is the frequent occurrence of Robinia pseudacacia, Quercus rubra, Padus serotina, and Mahonia aquifolium found in the majority of forest communities documented in the study area, with the exception of a few wellpreserved fragments of natural habitats. In many places, xenospontaneous forest communities included in the Chelidonio-Robinietum association or scrub with the participation of alien shrub species have developed. Among highly invasive species, Bidens frondosa, Elodea canadensis, Impatiens glandulifera, I. parviflora, Lupinus polyphyllus, Reynoutria japonica, Symphoricarpos albus, Solidago gigantea, and Spiraea salicifolia should also be mentioned.

The second major threat is the abandonment of seminatural habitats. Consequently, most of the meadow communities within the study area are subject to degenerative changes due to natural succession.

\section{Spatial Analysis of the Location of Geotopes and Places of High Biodiversity}

It was found that areas with a high level of biodiversity, which are particularly attractive from the perspective of nature conservation and educational opportunities, occupy a significant amount of space within the landscape park. There were 428.4 ha of highly diverse plant sites and 390.6 ha of such animal sites in the study area (Fig. 2). The analysis of the relative location of objects of high biodiversity and geotopes revealed that 232.2 ha of the sites of plants $(54.2 \%)$ and 210.2 ha of the sites of animals $(53.8 \%$ ) are situated less than $1 \mathrm{~km}$ (15-min walk) from the nearest geotope (Fig. 2), 
Fig. 2 Distribution of geotopes and objects crucial for diversity within the study area (Muskau Arch Landscape Park). 1

Glaciotectonic deformation area of the push moraine. 2 Boundary of the landscape park. 3 Location of the geotope and a buffer with a radius of $1 \mathrm{~km} .4$ Crucial plant sites. 5 Crucial animal sites. Insets 1-3 Erosive forms and vegetation on the shore of the anthropogenic reservoir "Africa." Inset 4 Typical of post-mining soils - fungus Pisolithus arenarius on sandy soil of the coastal zone of the reservoir Africa. Inset 5 Mattheucia strutiopteris in the riparian forests (habitat *91E0) of Natura 2000 site PLH080060 "Uroczyska Borów Zasieckich.” Inset 6 Old riparian forest stand StellarioAlnetum association (habitat *91E0). Inset 7 Old oakhornbeam forests of the Galio sylvatici-Carpinetum association (habitat 9170) in the nature reserve "Nad Młyńską Strugą"

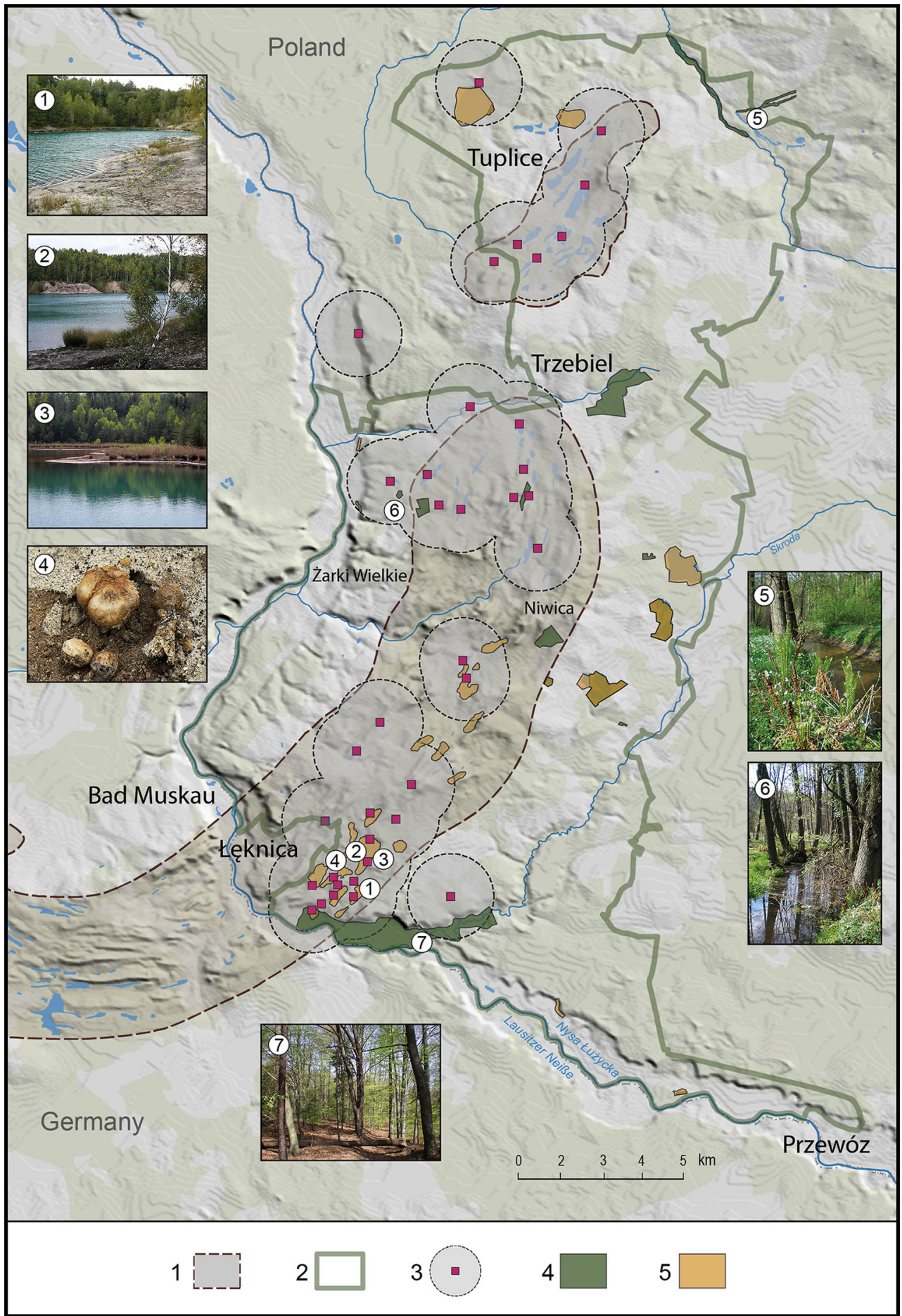

whereas, within a distance of $5 \mathrm{~km}$ (10-min travel by car), $100 \%$ of valuable animal sites and $99.5 \%$ of plant sites can be found.

These results indicate a high coherence of the area in terms of geodiversity and valuable elements of flora, fauna, and mycobiota. The average distance between the groups of geotopes is $1.23 \mathrm{~km}$, and the minimum length of a tourist route connecting all objects would be $40.25 \mathrm{~km}$.

\section{Discussion}

\section{Complementarity of Geo- and Biodiversity}

The results indicate that biodiversity and geological diversity which coexist within the Muskau Arch could be an essential element for supporting the tourist and educational functions at the site and contributing to the site's attractiveness overall. 
The occurrence of so many plant and animal species which are currently protected in the EU or included in the national red lists of endangered species is surprising within the study area-all the more so because this region was transformed due to its exploitation via mining, which ended in the late nineteenth and early twentieth century in the northern part of the area and only in 1973 in the southern part, as well as very intensive agriculture and forestry development.

The proximity of valuable ecosystems and geotopes enables the coherent development of space where they are protected and put on display; this is valuable because one of the motivations for visiting the geosites are the esthetics of the landscape, which largely depends on the richness of vegetation (Zgłobicki and Baran-Zgłobicka 2013). The analysis, which was performed for the Dębnica River drainage basin in Poland using GIS methods also revealed the coexistence of areas of very high geodiversity and biodiversity which had previously been hotspots for local natural and cultural geoheritage (Mazurek et al. 2015). Moreover, the analysis of the patch-scale relationship for the landscape transformed by the quarries of quartzite in France revealed a strong connection between quarrying landforms and biological assemblages at the patch scale (Bétard 2013).

The relationship between biotic and abiotic elements is certainly not the only feature which influences the attractiveness of a region's geoheritage. The numerous examples demonstrated by Dowling (2010) include various types of geoparks, including those where the lack of vegetation cover plays a role (e.g., Valley of the Moon, Atacama Desert, Chile or The World of Fire, Vestmannaeyjar, Iceland).

\section{Educational Value of Complementarity}

Related to the second goal of this study, the spatial proximity of biotic and abiotic components within the geoheritage site facilitates the design of new tourist trails, educational tracks, and info points.

Tourist use of the existing geotouristic path "Dawna Kopalnia Babina", with a length of $5 \mathrm{~km}$, reached almost 16,000 visits in 2013 (http://www.geosciezkababina.pl/pl. html?start=3, accessed May 7, 2015). The peak of visits was recorded in summer months (especially August) as well as on Sundays during the May-June period (Koźma 2013). This confirms the results of research conducted in the regions of Southeastern Poland with similar geological and landscape values (Zgłobicki and Baran-Zgłobicka 2013) , revealing that the most of the visits were a part of car trips (Sundays) or walking excursions during a long-term stay (holidays).

This research further found that in the case of the first type of activity (car trips), all objects of high biodiversity within the studied geotope zones are available, and for walking excursions, more than half of these sites are accessible. However, the significant distance between geotopes as well as the minimum length of a trail connecting all of them (over $40 \mathrm{~km}$ in a straight line) suggest that the tourist and educational use of the objects would be best oriented around four independent centers located 4-5 km from one another (Łęknica, Niwica, Trzebiel, Tuplice). Within these places, all geotopes available during walking excursions should be described.

Of the currently existing trails and educational tracks, only "Dawna Kopalnia Babina" track (5-km length), "Od Hydro do Kucyka" track (6-km length), and a cycle-car track "Wzdhuż Łuku" provide access to some attractive objects of geo- and biodiversity. In general, the geo- and biodiverse elements in Muskau Arch are not situated at the same locations and there is no direct connection between them. Most of the valuable geotopes within the boundaries of the geoheritage area are anthropogenic in origin, while high-value natural and semi-natural habitats have not been influenced by intensive human impact and represent fragments of ecosystems retained from the period before the intensive extraction of mineral deposits in the area.

Anthropogenic biotopes with features valuable from both a bio- and geodiversity point of view and whose simultaneous presentation on educational track/nature trail is possible are uncommon in the area. One of them is an artificial, acidic body of water (min. pH 2.3; Bożęcki 2013) called "Africa," located in the area of former open-cast mine where the chemolithoautotrophic bacterium Acidithiobacillus ferrooxidans occurs abundantly. This bacterium, which metabolizes iron and sulfur and produces sulfuric acid, is responsible for the biogenic corrosion of the local iron pyrite deposits. Also, a spherical fungus Pisolithus arrhizus can be found on the slopes of the artificial lake. This mycorrhizal species is considered a powerful root stimulator and is especially distributed in the areas of degraded or polluted lands.

\section{Possible Conflicts between Geo- and Biodiversity}

Despite the identified biodiversity within the study area, the disappearance of eight critically endangered or extinct (in Poland) vascular plants and the likely loss of further 17 valuable species were recorded. This impoverishment of flora corresponds to the theses of Petrişor and S bru (2010), who suggested that the increase in the number of geotopes within anthropogenically transformed areas may be accompanied by the impairment of natural ecosystems and the loss of some key elements of local biodiversity.

The degradation of a large part of the ecosystems (especially forest ones) and the abundant occurrence of invasive alien species, including trees and shrubs, is the consequence of anthropogenic changes which took place between the nineteenth and the second half of the twentieth century.

In terms of management, geosites are often a space for conflict between geo- and biological conservation (Gray 
2004; Crofts and Gordon 2015), as the preservation of geological value and the maintenance of a site's visibility may require systematic vegetation clearance (Dowling and Newsome 2006).

The character of this conflict depends on the history of the geosite and the origin of geotopes. It might be especially significant at sites where valuable objects of geological heritage are, at the same time, habitats for rare species of vascular plants or bryophytes, i.e., when natural habitats develop over different types of volcanic, sedimentary, or metamorphic rocks in montane regions. However, on moraines within unconsolidated deposits, these types of conflicts are rare, as in, e.g., the areas covered by sand dunes (Bruneau et al. 2011). In the case of the Muskau Arch Geoheritage, rare species of animals and plants, as well as other plant communities, occur in close proximity to geotopes, though not directly in the area of rock outcrops or excavations. This effectively minimizes potential conflicts.

The geological heritage sites of particular importance in Muskau Arch Geopark due to their recent and anthropogenic origin are covered by pioneer vegetation. This vegetation comprises exclusively common trees, shrubs, and herbaceous plant species. Since the areas where the geological and natural values occur do not overlap directly in the field, it is possible to make use of various kinds of conservation treatments together-some specific to geological objects (vegetation clearance, activities connected with the provision of field access by means of a construction of footbridge or well-tended trails), and others for objects of high natural value (e.g., hay cutting in meadows, passive protection of forests or nesting zones of birds, halting the outflow of water from peat bogs, active conservation of individual plant species).

Therefore, both components of the geopark area (abiotic and biotic) can be independently managed, avoiding the need to choose between different protection objectives (Gordon et al. 2015). As such, the existence of endangered species of birds is not in conflict with a desire to use geological objects educationally. The majority of recorded birds need to nest in wooded areas outside the geotopes, but they frequently use the feeding grounds inside the areas. It enables the observation of the foraging behavior of birds of prey or kingfishers, the passage routes of black stork, or tooting behavior of cranes.

The analyzed region provides an example of how to reconcile the necessary protection of bio- and geodiversity; however, its suitability is partly due to the special historical and geographical conditions which have influenced its formation.

Because a large proportion of local geotopes are those of anthropogenic origin, their formation was accompanied by a loss of biodiversity in the past, as evidenced by the loss of some species of vascular plants, for example.

Such changes manifesting clearly in the landscape and influencing the present state of ecosystems are nothing new (Bruneau et al. 2011). However, the current state, wherein scientifically and didactically valuable geological objects are located in close vicinity to sites of high natural value, is possible to maintain, as long as there is attention paid to the equal treatment of both components of the geopark and a simultaneous application of protection methods for each of them.

This approach is in accordance with the holistic approach to conservation presented by many authors (e.g., Prosser et al. 2010; Gordon et al. 2012; Gordon and Barron 2013; Crofts 2014; Crofts and Gordon 2015). In the Muskau Arch Geopark, geo- and biodiversity values are thus equal in terms of their significance, even if their location in the landscape is entirely different. However, a more integrated approach to the conservation of the area would benefit both biodiversity and geodiversity, as suggested by Gordon et al. (2015).

Acknowledgments The authors are grateful to Dr. Remigiusz Pielech, Dr. Monika Dimos, and M. Sc. Małgorzata Rudy for their help during field work. Special thanks also go to Amanda Anthony who kindly improved our English and two anonymous reviewers for their valuable comments on previous version of the manuscript.

Open Access This article is distributed under the terms of the Creative Commons Attribution 4.0 International License (http:// creativecommons.org/licenses/by/4.0/), which permits unrestricted use, distribution, and reproduction in any medium, provided you give appropriate credit to the original author(s) and the source, provide a link to the Creative Commons license, and indicate if changes were made.

\section{References}

Alexandrowicz A, Margielewski W (2010) Impact of mass movements on geo- and biodiversity in the Polish outer (flysch) Carpathians. Geomorphology 123:290-304

Alexandrowicz Z, Urban J, Miśkiewicz K (2009) Geological values of selected polish properties of the UNESCO world heritage list. Geoheritage 1:43-52

Babczyńska-Sendek B, Błońska A, Kołtuniak A (2012) Excavations of the Twardowice Plateau (Silesian Upland) as refuges for xerothermic plant species. Biodiv Res Conserv 28:29-36

Badora K, Hebda G, Nowak A, Nowak S (2003) Bio- and geodiversity of upper carst limestone excavations in the Opole City. Nat J 36:35-69

Badura J, Gawlikowska E, Kasiński JR, Koźma J, Kupetz M, Piwocki M, Rascher J (2002) Geopark ,Łuk Mużakowa”-proponowany transgraniczny obszar ochrony georóżnorodności. Prz Geol 51:54-58

Beneš J, Kepka P, Konvička M (2003) Limestone quarries as refugees for European xerophilous butterflies. Conserv Biol 17:1058-1069

Bétard F (2013) Patch-scale relationships between geodiversity and biodiversity in hard rock quarries: case study from a disused quartzite quarry in NW France. Geoheritage 5:59-71

Bożęcki P (2013) Studium osadów tworzących się w obszarze eksploatacji węgla brunatnego w rejonie Łęknicy (Łuk Mużakowa). Akademia Górniczo-Hutnicza im. Stanisława Staszica, PhD Thesis, Kraków. [online http://winntbg.bg.agh.edu. pl/rozprawy2/10660/full10660.pdf]

Brocx M, Semeniuk V (2007) Geoheritage and geoconservation-history, definition, scope and scale. J R Soc West Aust 90:53-87

Bruneau PMC, Gordon JE, Rees S (2011) Ecosystem sensitivity and responses to change: understanding the links between geodiversity 
and biodiversity at the landscape scale. JNCC Report No 450, Peterborough, pp. 1-55

Cieśliński S, Czyżewska K, Fabiszewski J (2006) Red list of the lichens in Poland. In: Mirek Z, Zarzycki K, Wojewoda W, Szeląg Z (eds) Red list of plants and fungi in Poland. W. Szafer Institute of Botany Polish Academy of Sciences, Kraków

Crofts R (2014) Promoting geodiversity: learning lessons from biodiversity. Proc Geol Assoc 125:263-266

Crofts R, Gordon JE (2015) Geoconservation in protected areas. In: Worboys GL, Lockwood M, Kothari A, Feary S, Pulsford I (eds) Protected area governance and management. ANU Press, Canberra, pp. 531-567

Dowling RK (2010) Geotourism's global growth. Geoheritage 3:1-13

Dowling RK, Newsome D (eds) (2006) Geotourism. Elsevier Ldt, Oxford

Dyjor S, Chlebowski W (1973) Budowa geologiczna polskiej części Łuku Mużakowa. Acta Univ Wratisl Pr Geol Miner 192:3-41

Erikstad L (2014) Geodiversity, biodiversity and landscape-key elements in modern nature management strategies. Geophys Res Abstr 16:EGU2014-EGU3961

Fałtynowicz W (2003) The lichens, lichenicolous and allied fungi of Poland - an annotated checklist. W. Szafer Institute of Botany Polish Academy of Sciences, Kraków

Gordon JE, Barron HF (2012) Valuing geodiversity and geoconservation: developing a more strategic ecosystem approach. Scott Geogr J 128: 278-297

Gordon JE, Barron HF (2013) The role of geodiversity in delivering ecosystem services and benefits in Scotland. Scott J Geol 49:41-58

Gordon JE, Barron HF, Hansom JD, Thomas MF (2012) Engaging with geodiversity - why it matters. Proc Geol Assoc 123:1-6

Gordon JE, Crofts R, Díaz-Martínez E (2015) IUCN recognition of geoheritage values and the development of management principles and guidelines for geoconservation in protected areas. Programme and Abstracts. VIII International ProGEO Symposium "2015 Geoconservation strategies in a changing world", 8-12 September 2015 Reykjavík, Iceland, Pp 39-40

Gray M (2004) Geodiversity: valuing and conserving abiotic nature. John Wiley and Sons Ltd., Chichester

Gray M (2005) Geodiversity and geoconservation: what, why, and how? In: Santucci VL (ed) Geodiversity \& Geoconservation, The George Wright Forum 22:4-12

Gray M, Gordon JE, Brown EJ (2013) Geodiversity and the ecosystem approach: the contribution of geoscience in delivering integrated environmental management. Proc Geol Assoc 124:659-673

Greinert H, Drab M, Greinert A (2009) Studia nad efektywnością leśnej rekultywacji zwałowisk fitotoksycznie kwaśnych piasków mioceńskich po byłej kopalni węgla brunatnego w Łęknicy. Oficyna Wydawnicza Uniwersytetu Zielonogórskiego, Zielona Góra

Herbichowa M, Rosadziński S (2014) Rhynchospora fusca (L.) W.T. Aiton. In: Kaźmierczakowa R, Zarzycki K, Mirek Z (eds) Polish red data book of plants. Pteridophytes and flowering plants, 3rd edn. Institute of Nature Conservation Polish Academy of Sciences, Kraków, pp. pp. 686-pp. 689

Herbichowa M, Rosadziński S, Jackowiak B (2014) Eleocharis multicaulis Desv. In: Kaźmierczakowa R, Zarzycki K, Mirek Z (eds) Polish red data book of plants. Pteridophytes and flowering plants, 3rd edn. Institute of Nature Conservation Polish Academy of Sciences, Kraków, pp. pp. 677-pp. 680

Hjort J, Heikkinen RK, Luoto M (2012) Inclusion of explicit measures of geodiversity improve biodiversity models in a boreal landscape. Biodivers Conserv 21:3487-3506

Houshold I, Sharples C (2008) Geodiversity in the wilderness: a brief history of geoconservation in Tasmania. (In:) Burek CV and Prosser CD (eds) The history of geoconservation. Geol Soc Lond, Spec Publ 300:257-272
Jankowski W, Świerkosz K (eds) (1995) Oder as an ecological corridor. State - Functioning - Threats. IUCN Poland, Warsaw

Jędrzejczyk-Korycińska M (2006) Floristic diversity in calamine areas of the Silesia-Cracow Monocline. Biodiv Res Conserv 3-4:340-343

Jerzak L (2005) Flora und fauna des muskauer faltenbogens. In: Koźma J (eds) Muskauer Park und die geotouristischen Sehenswürdigkeiten in der umgebung von Łęknica. Łęknica, pp. 72-89

Kasiński JR, Koźma J, Gawlikowska E (2004) Geotopes of the proposed Muskau Arch Geopark - inventory, classification and evaluation. Pol Geol Inst Spec Pap 13:73-88

Kaźmierczakowa R, Zarzycki K, Mirek Z (2014) Polish red data book of plants. Pteridophytes and flowering plants, 3rd edn. Institute of Nature Conservation Polish Academy of Sciences, Kraków

Kiernan K (2010) Human impacts on geodiversity and associated natural values of Bedrock Hills in the Mekong Delta. Geoheritage 2: $101-122$

Koźma J (2011) Transgraniczny geopark Łuk Mużakowa. Prz Geol 59: $276-290$

Koźma J (2013) Geotouristic "Babina" path as an example of sustainable development in the Muskau Arch Geopark. Rendiconti Online Società Geologica Italiana 28:93-96

Koźma J, Kupetz M (2008) The transboundary geopark Muskau Arch. Prz Geol 52:692-698

Kupetz M (1997) Geologischer bau und genese der Stauchendmoräne Muskauer Faltenbogen. Brandenburgische Geowiss Beitr 4:1-20

Kupetz M (2003) Die geomorphologie des Muskauer Faltenbogens im hochauflösenden digitalen Geländemodell. Brandenburgische Geowiss Beitr 10:19-28

Kupetz A, Kupetz M (2009) Der Muskauer Faltenbogen. Verlag dr. Freidrich Pfeil, München

Matthews TJ (2014) Integrating geoconservation and biodiversity conservation: theoretical foundations and conservation recommendations in a European Union context. Geoheritage 6:57-70

Mazurek M, Najwer A, Borysiak J, Gudowicz J, Zwoliński Z (2015) From geodiversity and biodiversity through geoheritage to geoconservation; case study for the Dębnica River drainage basin (Poland). Geophys Res Abstr 17:EGU2015-EGU7870

Mirek Z, Piękoś-Mirkowa H, Zając A, Zając M (2002) Flowering plants and pteridophytes of Poland - a checklist. Biodiversity of Poland. vol. 1. W. Szafer Institute of Botany Polish Academy of Sciences, Kraków

Moreira JC (2010) Interpretative panels about the geological heritage - a case study at the Iguassu Falls National Park (Brazil). Geoheritage 4: $127-137$

Musila W, Todt H, Uster D, Dalitz H (2005) Is geodiversity correlated to biodiversity? A case study of the relationship between spatial heterogeneity of soil resources and tree diversity in a Western Kenyan Rainforest. In: Huber BA, Sinclair BJ, Lampe KH (eds) African Biodiversity. Springer US, New York, pp. pp. 405-pp. 414

Novák J, Prach K (2003) Vegetation succession in basalt quarries: pattern on a landscape scale. Appl Veg Sci 6:111-116

Nowak S, Nowak A (2013) The role of rock mining for maintaining Dauco carotae-Crepidetum rhoeadifoliae Hejný et Grüll in Hejný et al. 1979 - a new to Poland plant association. Cent Eur J Biol 8: 799-812

Pawlaczyk A (1999) Flora roślin naczyniowych. In: Sołowiej D, Błoszyk J (eds) Podstawy ekorozwoju ,zielonej Wstęgi Odra-Nysa”. Wydawnictwo Kontekst, Poznań

Petrişor AI, S bru CN (2010) Dynamics of geodiversity and eco-diversity in territorial systems. J Urban Reg Anal 2:61-70

Popiela A, Łysko A, Konopska K, Rosadziński S (2014a) Elatine hexandra (Lapierre) DC. In: Kaźmierczakowa R, Zarzycki K, Mirek Z (eds) Polish red data book of plants. Pteridophytes and flowering plants, $3 \mathrm{rd}$ edn. Institute of Nature Conservation Polish Academy of Sciences, Kraków, pp. pp. 339-pp. 341

Popiela A, Łysko A, Janukowicz M, Rosadziński S (2014b) Elatine triandra Schkuhr. In: Kaźmierczakowa R, Zarzycki K, Mirek Z 
(eds) Polish red data book of plants. Pteridophytes and flowering plants, 3rd edn. Institute of Nature Conservation Polish Academy of Sciences, Kraków, pp. pp. 337-pp. 339

Prosser CD, Burek CV, Evans DH, Gordon JE, Kirkbride VB, Rennie AF, Walmsley CA (2010) Conserving geodiversity sites in a changing climate: management challenges and responses. Geoheritage 2:123136

Rascher J, Meier J, Kupetz M (2000) Der Geopark Muskauer Faltenbogen-grundlagen, Stand, perspektiven. geowiss. mitt. Thüringen. Beih 10:75-85

Santucci V (2005) Historical perspectives on biodiversity and geodiversity. Geodiversity Geoconservation 22:29-34

Szczęśniak E (1999) Sudeckie murawy naskalne siedlisk naturalnych i antropogenicznych - zróżnicowanie, sukcesja i ochrona. Lubuski Przegląd Przyrodniczy 10:59-68

Szmeja J (2014) Luronium natans (L.) Raf. In: Kaźmierczakowa R, Zarzycki K, e (eds) Polish red data book of plants. Pteridophytes and flowering plants, $3 \mathrm{rd}$ edn. Institute of Nature Conservation Polish Academy of Sciences, Kraków, pp. pp. 556-pp. 557

Weigle A (2007) Plan ochrony parku krajobrazowego Łuk Mużakowa. Narodowa Fundacja Ochrony Środowiska, Warszawa
Wheater CP, Cullen WR (1997) The flora and invertebrate fauna of abandoned limestone quarries in Derbyshire. United Kingdom Res Ecol $5: 77-84$

Wojewoda W (2003) Checklist of Polish larger Basidiomycetes. In: Mirek Z (ed) Biodiversity of Poland Vol. 7. W. Szafer Institute of Botany, Polish Academy of Sciences, Kraków

Wojewoda W, Ławrynowicz M (2006) Red list of the macrofungi in Poland. In: Mirek Z, Zarzycki K, Wojewoda W, Szelag Z (eds) Red list of plants and fungi in Poland. Polish Academy of Sciences. W. Szafer Institute of Botany Polish Academy of Sciences, Kraków, pp. pp. 53-pp. 70

Zgłobicki W, Baran-Zgłobicka B (2013) Geomorphological heritage as a tourist attraction. A case study in Lubelskie Province, SE Poland. Geoheritage 5:137-149

Żukowski W, Jackowiak B, Celka Z (2014a) Apium nodiflorum (L.) Lag. In: Kaźmierczakowa R, Zarzycki K, Mirek Z (eds) Polish red data book of plants. Pteridophytes and flowering plants, 3rd edn. Institute of Nature Conservation Polish Academy of Sciences, Kraków, pp. pp. 358-pp. 360

Żukowski W, Jackowiak B, Szczęśniak E, Rosadziński S (2014b) Pilularia globulifera L. In: Kaźmierczakowa R, Zarzycki K, Mirek Z (eds) Polish red data book of plants. Pteridophytes and flowering plants, 3rd edn. Institute of Nature Conservation Polish Academy of Sciences, Kraków, pp. pp. 73-pp. 75 